E-JURNAL EKONOMI DAN BISNIS UNIVERSITAS UDAYANA
Available online at https://ojs.unud.ac.id/index.php/EEB/index
Vol. 10 No. 06, June 2021, pages: 511-524
e-ISSN: 2337-3067

\title{
PENGARUH KUNJUNGAN WISATAWAN DAN RATA-RATA PENGELUARAN WISATAWAN TERHADAP PAD DAN PERTUMBUHAN EKONOMI PROVINSI BALI
}

I Gede Dea Joendra Septyana Putra ${ }^{1}$ Ni Luh Karmini² I Wayan Wenagama ${ }^{3}$

Article history:

Submitted: 28 Maret 2021

Revised: 2 April 2021

Accepted: 6 April 2021

\section{Keywords:}

Tourists;

Expenses;

Income;

Economic Growth;
Kata Kunci:

Wisatawan;

Pengeluaran;

Pendapatan;

Pertumbuhan Ekonomi;

\section{Koresponding: \\ Fakultas Eknomi dan Bisnis, Universitas Udayana, Bali, Indonesia \\ Email : igd. \\ Deajohendraseptiana.p@gmial. com}

Abstract

This study aims to analyze the effect of the number of tourist visits and the average tourist expenditure on the local income of Bali Province, to analyze the effect of the number of tourist visits, average tourist expenditure, and local income on the economic growth of Bali Province, and to analyze the role of income. native areas in mediating the effect of the number of tourist visits and the average tourist expenditure on the economic growth of Bali Province. The data used in this research is secondary data, with the method of observation by observing documents or secondary data sources that are related. This study uses time series data with a total of 30 years of observations from 1990-2019, with the analysis technique used is Path Analysis. This study shows the results that the number of tourist visits and the average tourist expenditure have a positive and significant effect on local income in Bali Province. The number of tourist visits, the average tourist expenditure and local revenue have a positive and significant effect on economic growth in Bali Province. Own-source revenue mediates the effect of the number of tourist visits and the average tourist expenditure on economic growth in Bali Province.

Abstrak

Penelitian ini bertujuan untuk menganalisis pengaruh jumlah kunjungan wisatawan dan rata-rata pengeluaran wisatawan terhadap pendapatan asli daerah Provinsi Bali, untuk menganalisis pengaruh jumlah kunjungan wisatawan, rata-rata pengeluaran wisatawan, dan pendapatan asli daerah terhadap pertumbuhan ekonomi Provinsi Bali, dan untuk menganalisis peran pendapatan asli daerah dalam memediasi pengaruh jumlah kunjungan wisatawan dan rata-rata pengeluaran wisatawan terhadap pertumbuhan ekonomi Provinsi Bali. Penelitian ini menggunakan data time series dengan jumlah pengamatan sebanyak 30 tahun dari tahun 1990-2019, dengan teknik analisis yang digunakan yaitu Path Analysis. Penelitian ini menunjukkan hasil bahwa jumlah kunjungan wisatawan dan rata-rata pengeluaran wisatawan berpengaruh positif dan signifikan terhadap pendapatas asli daerah di Provinsi Bali. Jumlah kunjungan wisatawan, rata-rata pengeluaran wisatawan dan pendapatan asli daerah berpengaruh positif dan signifikan terhadap pertumbuhan ekonomi di Provinsi Bali. Pendapatan asli daerah memediasi pengaruh jumlah kunjungan wisatawan dan rata-rata pengeluaran wisatawan terhadap pertumbuhan ekonomi di Provinsi Bali. 


\section{PENDAHULUAN}

Pariwisata merupakan sub sektor unggulan yang menjadi salah satu penghasil sumber devisa bagi negara. Keberadaan sub sektor pariwisata disetiap wilayah di Indonesia memberikan dampak yang cukup baik bagi perkembangan wilayahnya, mulai dari membangkitkan tatanan perbaikan perekonomian daerah, membangkitkan kreativitas dan inovasi penduduk lokal, serta dapat berdampak bagi kesejahteraan masyarakat diarea sekitar pariwisata. Keberadaan pariwisata di Indonesia yang telah dinilai dunia memiliki potensi dan keanekaragaman wisata yang cukup potensial, mulai dari wisata alam, laut, sosial dan budaya yang tersebar dari sabang sampai merauke (Hellen \& Soemanto, 2017). Selain menyimpan pesona parwisata alamnya yang begitu indah, Indonesia juga kaya akan wisata budaya yang terbukti dengan begitu banyaknya peninggalan sejarah, seni dan adat budaya masyarakat lokal yang menarik wisatawan lokal maupun wisatawan mancanegara untuk datang dan menikmati keanekaragaman wisata tersebut.

Salah satu wilayah yang telah terkenal dunia akan keindahan pariwisatanya yaitu Bali. Provinsi Bali atau yang sering disebut sebagai The Island of Paradise merupakan wilayah yang menyimpan berbagai keindahan dan potensi unggulan pariwisata mulai dari keindahan bentangan alam (laut, gunung, dan danau), penduduk yang tentram dan ramah, serta kebudayaan yang menjadi identitas tersendiri bagi kearifan lokal pariwisata bali. Pengembangan pariwisata bali harus dapat dimaksimalkan guna mewujudkan pariwisata yang berkelanjutan. Pariwisata yang berkelanjutan adalah proses pembangunan dibidang pariwisata dengan mengedepankan prinsip-prinsip pembangunan yang mencakup kelestarian alam dan lingkungan (ecological sustainability), melestarikan budaya dan kearifan lokal daerah setempat (social and cultural sustainability) dan keberlanjutan ekonomi yang dapat dipertahankan baik untuk generasi yang sekarang maupun yang akan datang (economic sustainability) (Disparda Provinsi Bali, 2020).

Penerapan konsep pembangunan pariwisata yang berkeberlanjutan dapat memberikan dampak yang positif terhadap keberadaan lingkungan dan ekonomi masyarakat lokal, serta berdampak positif pada lingkungan sosial maupun kebudayaan di wilayah tersebut (Nurhasanah dkk, 2017). Dengan adanya pembangunan pariwisata yang berkelanjutan ini, berjalannya usaha pariwisata akan dapat memaksimalkan proses kemajuan pembangunan diwilayah setempat, menjaga kepuasan wisatawan, dan dapat berkontribusi lebih besar dalam memajukan perekonomian wilayah. Selain itu menggali sumber potensi lokal wilayah sangat diperlukan guna mendukung kontribusi terhadap kesejahteraan masyarakat (Rimayanti \& Arka, 2019).

Kemajuan dibeberapa sektor pariwisata dibali memiliki dua sisi/dampak terhadap pembangunan wilayah. Pembangunan pariwisata dapat berdampak positif terhadap pembangunan wilayah apabila usaha disektor pariwisata tersebut dikembangkan secara terpadu maka akan berdampak bagi kemajuan perekonomian diwilayah setempat. Pariwisata telah terbukti dapat mendorong pertumbuhan perekonomian melalui peluang investasi, peluang kerja, peluang berusaha dan pada akhirnya dapat meningkatkan kesejahteraan masyarakat. Peluang berusaha bukan hanya dalam bentuk pembangunan sarana dan prasarana pariwisata tetapi juga peluang dalam bidang kerajinan kecil untuk mendorong peningkatan partisipasi masyarakat lokal serta membangkitkan sektor ekonomi rumah tangga (Martina, 2014; dan Sigit 2014).

Kemajuan perekonomian wilayah dari kemajuan sektor pariwisata akan membawa dampak yang baik dari kondisi pertumbuhan ekonomi wilayah. Pertumbuhan ekonomi menurut (Sukirno, 2010) merupakan perkembangan kegiatan dalam perekonomian yang berdampak terhadap peningkatan produksi barang dan jasa yang ada di masyarakat. Pertumbuhan ekonomi menunjukkan peningkatan

Pengaruh Kunjungan Wisatawan Dan Rata-Rata Pengeluaran Wisatawan Terhadap PAD Dan Pertumbuhan 
dalam produksi barang maupun jasa dalam suatu perekonomian, sehingga pertumbuhan ekonomi ini merupakan salah satu indikator penting di dalam melakukan suatu analisis kemajuan pembangunan ekonomi wilayah (Nuraini, 2017). Perkembangan perekonomian pada suatu wilayah biasanya tercermin dari pertumbuhan Produk Domestik Regional Bruto (PDRB) atas dasar harga konstan, karena PDRB merupakan komponen pembangunan sub sektor perekonomian wilayah yang sangat penting untuk mengukur keberhasilan pembangunan ekonomi di era otonomi daerah saat ini. Berikut disajikan data pertumbuhan PDRB menurut kabupaten/kota.

Berdasarkan data Tabel 1, dapat diketahui bahwa laju pertumbuhan ekonomi menurut kabupaten/kota di Provinsi Bali dari tahun 2015 hingga 2019 mengalami fluktuatif, namun terdapat dua kabupaten/kota yang memiliki pertumbuhan ekonomi melebihi pertumbuhan ekonomi Bali secara berturut-turut selama 5 tahun terakhir yakni Kota Denpasar dan juga Kabupaten Badung. Perkembangan laju pertumbuhan ekonomi tersebut sangat besar dipengaruhi oleh kestabilan perekonomian wilayah, mulai dari laju inflasi, deflasi, minat konsumsi masyarakat, serta peranan masing-masing sektor perekonomian di wilayah Provinsi Bali. Salah satu yang mendukung kemajuan pertumbuhan ekonomi di Provinsi Bali yaitu karena berkembangnya sektor pariwisata di Bali. Sesuai dengan penelitian Pertiwi (2014), pariwisata mampu menghasilkan kontribusi yang signifikan terhadap perekonomian dalam suatu wilayah, karena sektor pariwisata merupakan salah satu industri yang mampu mendorong tumbuhnya pertumbuhan ekonomi dengan cepat dalam hal penyediaan lapangan kerja, pendapatan, taraf hidup, dan dalam mengaktifkan sektor produksi lainnya.

Tabel 1.

Laju Pertumbuhan Ekonomi Kabupaten/Kota di Provinsi Bali Tahun 20152019

\begin{tabular}{cccccc}
\hline \multirow{2}{*}{ Kabupaten/Kota } & \multicolumn{5}{c}{ Tahun (Persen) } \\
\cline { 2 - 6 } & $\mathbf{2 0 1 5}$ & $\mathbf{2 0 1 6}$ & $\mathbf{2 0 1 7}$ & $\mathbf{2 0 1 8}$ & $\mathbf{2 0 1 9}$ \\
\hline Jembrana & 6.19 & 5.96 & 5.28 & 5.59 & 5.56 \\
Tabanan & 6.19 & 6.14 & 5.37 & 5.73 & 5.60 \\
Badung & 6.24 & 6.81 & 6.08 & 6.74 & 5.83 \\
Gianyar & 6.30 & 6.31 & 5.46 & 6.03 & 5.64 \\
Klungkung & 6.11 & 6.28 & 5.32 & 5.50 & 5.44 \\
Bangli & 6.16 & 6.24 & 5.31 & 5.50 & 5.47 \\
Karangasem & 6.00 & 5.92 & 5.06 & 5.48 & 5.50 \\
Buleleng & 6.07 & 6.02 & 5.38 & 5.62 & 5.55 \\
Denpasar & 6.14 & 6.51 & 6.05 & 6.43 & 5.84 \\
\hline Provinsi Bali & $\mathbf{6 . 0 3}$ & $\mathbf{6 . 3 3}$ & $\mathbf{5 . 5 6}$ & $\mathbf{6 . 3 3}$ & $\mathbf{5 . 6 3}$ \\
\hline
\end{tabular}

Sumber : BPS Provinsi Bali, 2020

Perkembangan laju pertumbuhan ekonomi tersebut, tidak terlepas dari pengaruh kegiatan perekonomian wilayah khususnya pada sektor-sektor penyumbangan pendapatan asli daerah (PAD) yang tinggi. Salah satunya yakni sektor pariwisata. Pendapatan asli daerah merupakan penerimaan yang diperoleh oleh suatu wilayah dari sumber-sumber potensi daerahnya sendiri yang dipungut berdasarkan aturan perundang-undangan yang berlaku. Menurut Undang-Undang Republik Indonesia Nomor 33 Tahun 2004, pendapatan asli daerah merupakan pendapatan daerah yang diperoleh berdasarkan peraturan daerah yang berlaku. Sumber pendapatan asli daerah itu sendiri terdiri dari hasil pajak daerah, hasil retribusi daerah, hasil pengelolaan kekayaan daerah yang dipisahkan, dan lain-lain pendapatan asli daerah yang sah.

Pengaruh Kunjungan Wisatawan Dan Rata-Rata Pengeluaran Wisatawan Terhadap PAD Dan Pertumbuhan 
Tabel 2.

Pendapatan Asli Daerah Kabupaten/Kota di Provinsi Bali Tahun 2015-2019

\begin{tabular}{lrrrrr}
\hline Kabupaten/ & \multicolumn{5}{c}{ Tahun (Ribu Rupiah) } \\
\cline { 2 - 6 } \multicolumn{1}{c}{ Kota } & \multicolumn{1}{c}{$\mathbf{2 0 1 5}$} & $\mathbf{2 0 1 6}$ & $\mathbf{2 0 1 7}$ & \multicolumn{1}{c}{$\mathbf{2 0 1 8}$} & $\mathbf{2 0 1 9}$ \\
\hline Jembrana & $98,032,646$ & $114,533,487$ & $121,342,475$ & $126,477,267$ & $133,698,784$ \\
Tabanan & $300,799,021$ & $318,083,799$ & $426,635,751$ & $363,370,469$ & $354,558,239$ \\
Badung & $3,001,464,263$ & $3,563,459,640$ & $4,172,457,396$ & $4,555,716,407$ & $4,835,188,460$ \\
Gianyar & $45,721,018$ & $529,864,618$ & $662,753,475$ & $770,204,849$ & $997,478,368$ \\
Klungkung & $120,035,996$ & $134,142,054$ & $153,210,776$ & $186,974,284$ & $225,063,772$ \\
Bangli & $87,731,141$ & $104,829,402$ & $104,592,163$ & $122,686,254$ & 127.040 .436 \\
Karangasem & $243,125,914$ & $318,083,799$ & $198,575,057$ & $200,361,247$ & $233,013,033$ \\
Buleleng & $293,038,467$ & $282,113,900$ & $455,195,426$ & $335,555,494$ & $365,595,301$ \\
Denpasar & $776,214,149$ & $807,050,192$ & $1,008,710,712$ & $940,110,335$ & $1,010,799,481$ \\
\hline Provinsi Bali & $\mathbf{3 , 0 4 1 , 2 6 6 , 6 0 7}$ & $\mathbf{3 , 0 4 1 , 1 9 5 , 2 5 8}$ & $\mathbf{3 , 3 9 8 , 4 7 2 , 2 7 8}$ & $\mathbf{3 , 7 1 8 , 4 9 9 , 6 3 5}$ & $\mathbf{4 , 0 2 3 , 1 5 6 , 3 1 6}$ \\
\hline Sumberyyyy$:$ BPS Provinsi Bali, 2020 & & & &
\end{tabular}

Sumber: BPS Provinsi Bali, 2020

Pada Tabel 2 diketahui bahwa PAD Provinsi Bali dari tahun ke tahun cenderung mengalami peningkatan, namun mengalami sedikit penurunan di tahun 2016 sebesar -0.002 persen, kemudian kembali mengalami peningkatan di tahun 2017 sebesar 11.75 persen dan ditahun 2018 sebesar 9.42 persen, dan ditahun 2019 sebesar 8.19 persen. Kabupaten/kota yang memiliki jumlah PAD tertinggi di Bali yakni Kabupaten Badung dan kedua ditempati oleh Kota Denpasar. Besaran PAD tinggi/rendah ditiap kabupaten/kota yang ada di Bali ditentukan dari seberapa banyak potensipotensi ekonomi yang dapat digali dan menghasilkan keuntungan berupa pajak, retribusi dan sumber pendapatan lainnya bagi daerah yang bersangkutan. Menurut Darmawan \& Wenagama (2017) yang menyatakan bahwa pengalokasian PAD pada suatu wilayah dengan baik dan tepat sasaran maka akan mampu memperkecil angka kemiskinan dan meningkatkan kesejahteraan masyarakat.

Menurut Sumawan \& Sukartha (2016), peningkatan penerimaan pendapatan asli daerah yang tinggi setiap tahunnya menunjukkan pula tingginya sumber keuangan yang dimiliki daerah. Potensi-potensi yang dimiliki daerah diharapkan agar mampu dimanfatkan dengan optimal sebagai sumber dari pendapatan asli daerah yang dapat meningkat (Taras \& Artini, 2017). Pengoptimalan peranan PAD sangatlah penting dalam mendukung kemajuan pembangunan wilayah serta mendukung laju pertumbuhan ekonomi wilayah yang semakin baik, khususnya dalam mendorong kemajuan di segala sektor ekonomi, mensejahterakan masyarakat serta mewujudkan pembangunan wilayah yang semakin merata dan berkeadilan.

Mendorong kemajuan pembangunan ekonomi wilayah khususnya pada peningkatan PAD diperlukannya pengoptimalan dalam memajukan sektor pariwisata, tidak dipungkiri bahwa sektor pariwisata di Bali sebagai penyumbang PAD khususnya pada pendapatan dari pajak dan retribusi usaha pariwisata. Menurut penelitian Swastika \& Yasa (2017), sektor pariwisata merupakan sektor yang potensial untuk dikembangkan sebagai salah satu sumber pendapatan asli daerah. Guna memperbesar pendapatan asli daerah tersebut, maka pemerintah perlu berupaya untuk mengembangkan dan memfasilitasi seluruh objek pariwisata agar sektor pariwisata dapat memberikan sumbangan bagi pembangunan ekonomi daerah. Salah satu upaya yang dapat dioptimalkan oleh pemerintah yaitu dengan menarik minat kunjungan wisatawan untuk mendukung pengembangan industri pariwisata dan pendapatan asli daerah sehingga wisatawan domestik maupun wisatawan mancanegara tertarik untuk berkunjung (Purwanti \& Dewi, 2014).

Pengaruh Kunjungan Wisatawan Dan Rata-Rata Pengeluaran Wisatawan Terhadap PAD Dan Pertumbuhan 
Fokus pengembangan pariwisata bali yang dikutip pada Dinas Pariwisata Provinsi Bali (2020) yang menyatakan bahwa arah pengembangan pariwisata bali saat ini yaitu difokuskan kepada pariwisata yang berbasis budaya, berorientasi pada kualitas, ramah lingkungan dan berjalan secara berkelanjutan dan berkesinambungan. Dengan adanya fokus pembangunan pariwisata tersebut, dapat berdampak bagi peningkatan jumlah kunjungan wisatawan serta terkenalnya kualitas pariwisata yang semakin baik di kancah dunia. Berikut disajikan data perkembangan jumlah kunjungan wisatawan menurut kawasan di Bali.

Tabel 3.

Perkembangan Kunjungan Wisatawan Pada Kawasan Objek dan Daya Tarik Wisata Menurut Kabupaten/Kota di Bali Tahun 2015-2019 (Orang)

\begin{tabular}{clrrrrr}
\hline No & Kabupaten/Kota & \multicolumn{1}{c}{$\mathbf{2 0 1 5}$} & \multicolumn{1}{c}{$\mathbf{2 0 1 6}$} & \multicolumn{1}{c}{$\mathbf{2 0 1 7}$} & \multicolumn{1}{c}{$\mathbf{2 0 1 8}$} & \multicolumn{1}{c}{$\mathbf{2 0 1 9}$} \\
\hline 1 & Denpasar & 455,961 & 440.202 & 570.236 & 2.081 .265 & 2.166 .192 \\
2 & Badung & $2,231,599$ & 3.571 .867 & 5.025 .941 & 4.816 .649 & 4.277 .052 \\
3 & Gianyar & $1,917,691$ & 2.953 .581 & 3.842 .208 & 4.550 .940 & 5.037 .459 \\
4 & Bangli & 610,349 & 694.583 & 790.822 & 703.010 & 1.230 .573 \\
5 & Klungkung & 372,051 & 378.894 & 496.176 & 253.235 & 503.347 \\
6 & Karangasem & 264,841 & 453.212 & 559.232 & 1.135 .119 & 1.165 .674 \\
7 & Buleleng & 694,704 & 698.494 & 954.730 & 1.003 .810 & 641.242 \\
8 & Jembrana & 156,247 & 180.514 & 280.526 & 309.508 & 291.951 \\
9 & Tabanan & $4,764,579$ & 5.203 .978 & 5.333 .823 & 5.533 .745 & 4.967 .424 \\
\hline & Bali & $\mathbf{1 1 , 4 6 8 , 0 2 2}$ & $\mathbf{1 4 . 5 7 5 . 3 2 5}$ & $\mathbf{1 7 . 8 5 3 . 6 9 4}$ & $\mathbf{2 0 . 3 8 7 . 2 8 1}$ & $\mathbf{2 0 . 2 8 0 . 9 1 4}$ \\
\hline
\end{tabular}

Sumber: BPS Provinsi Bali, 2020

Berdasarkan data pada Tabel 3 diketahui bahwa jumlah kunjungan wisatawan ke Bali dari tahun 2015 hingga 2018 mengalami tren peningkatan, namun sedikit mengalami penurunan di tahun 2019 yaitu sebesar -0.52 persen, dan terdapat beberapa kabupaten yang memang mengalami fluktuasi kunjungan jumlah wisatawan. Tingginya jumlah kunjungan wisatawan di beberapa wilayah di Provinsi Bali dikarenakan perbedaan dari segi jumlah kawasan/objek wisata serta keindahan objek wisatawan tersebut yang membuat objek tersebut dikunjungi oleh wisatawan. Peran serta partisipasi aktif dari masyarakat lokal dalam perencanaan mengelola kawasan pariwisata merupakan hal yang penting dalam membangun pariwisata yang berkelanjutan guna mendukung kemajuan dan peningkatan jumlah kunjungan wisatawan (Cole, 2006).

Banyaknya jumlah kunjungan wisatawan, akan berdampak baik apabila diiringi dengan kemampuan membeli/melakukan transaksi ketika sedang berkunjung ketempat wisata sehingga hal tersebut akan berdampak bagi semakin baiknya perputaran ekonomi diwilayah, serta dapat menambah sumbangan devisa bagi negara. Kontribusi devisa dari sektor pariwisata tersebut, akan mengamankan posisi negara untuk melakukan transasksi dengan dunia internasional (Dewi \& Urmila Dewi, 2019). Pengeluaran wisatawan adalah pengeluaran total yang dilakukan oleh wisatawan ketika mengunjungi suatu daerah yang menjadi tujuan wisata, besaran pengeluaran yang dilakukan wisatawan menjadi salah satu tolok ukor untuk menentukan perkembangan ekonomi dan pariwisata di daerah yang bersangkutan (Djulius \& Bilal, 2019). Sedangkan menurut Suartana dkk., (2018), pengeluaran wisatawan merupakan uang yang digunakan oleh wisatawan dalam melakukan kegiatan wisata mencangkup kebutuhan di tempat wisata seperti konsumsi, akomodasi dan trasportasi. Tingkat pengeluaran wisatawan sangat dipengaruhi oleh pola perilaku belanja wisatawan sehingga kunci

\footnotetext{
Pengaruh Kunjungan Wisatawan Dan Rata-Rata Pengeluaran Wisatawan Terhadap PAD Dan Pertumbuhan Ekonomi Provinsi Bali I Gede Dea Joendra Septyana Putra, Ni Luh Karmini dan I Wayan Wenagama
} 
penting dari meningkatkan perilaku ekonomis wisatawan dalam berbelanja yaitu dengan memberikan pemahaman dan pengalaman-pengalaman yang positif ketika mengunjungi sebuah destinasi wisata (Yoga dkk, 2018). Berikut disajikan data rata-rata pengeluaran wisatawan yang berkunjung ke Bali dari tahun 2015 hingga 2019.

Berdasarkan data pada Tabel 4, diketahui bahwa rata-rata pengeluaran wisatawan mancanegara dan domestik setiap tahunnya mengalami fluktuasi hal tersebut secara umum banyak disebabkan oleh kondisi ekonomi wilayah seperti inflasi dan nilai tukar rupiah yang berpengaruh terhadap wisatawan mancanegara khususnya, serta kemampuan dan minat beli wisatawan terhadap produk-produk yang tersedia ditempat wisata. Sehingga yang menjadi kunci penting adalah bagaimana peran serta pelaku ekonomi ditempat wisata dalam memberikan kesan yang positif dalam mendorong minat beli wisatawan.

Tabel 4.

Rata-rata Pengeluaran Wisatawan Mancanegara dan Domestik di Provinsi Bali, 2015-2019

\begin{tabular}{cccc}
\hline \multirow{2}{*}{ Tahun } & \multicolumn{2}{c}{ Pengeluaran $(\mathbf{R p})$} & \multirow{2}{*}{ Jumlah } \\
\cline { 2 - 3 } & Mancanegara & Domestik & 2.505 .376 \\
2015 & 1.985 .376 & 520.000 & 2.477 .394 \\
2016 & 1.927 .394 & 550.000 & 2.080 .941 \\
2017 & 1.611 .941 & 469.000 & 2.631 .302 \\
2018 & 2.056 .302 & 575.000 & 2.547 .730 \\
2019 & 2.017 .730 & 530.000 & \\
\hline
\end{tabular}

Sumber : BPS Provinsi Bali, 2020

Perkembangan Bali menjadi kawasan pariwisata kedepannya harus tetap memperhatikan kesinambungannya, sehingga pariwisata yang ada saat ini benar-benar dapat berjalan secara berkelanjutan dalam jangka panjang dengan tetap memperhatikan dampak positif dan negatifnya. Menurut Spillane (1994), dampak positif pariwisata terhadap pembangunan ekonomi antara lain yakni, dapat menciptakan peluang kerja/ekonomi bagi masyarakat sekitar, menyumbang sumber devisa bagi negara dan distribusi bagi pemerataan pembangunan daerah. Sedangkan dampak negatif pariwisata terhadap pembangunan ekonomi antara lain yaitu kebocoran pendapatan, sifat pekerjaan yang musiman, dan terhadap alokasi sumber daya ekonomi pariwisata dapat menimbulkan masalah-masalah besar seperti polusi air dan udara, kekurangan air, keramaian lalu lintas dan kerusakan dari pemandangan alam masalah lingkungan yang terkait dengan pariwisata, seperti polusi, masalah sampah, overconstruction dan degradasi sumber daya alam lainnya yang makin terlihat dampaknya (Ghimire., 2001).

Sesuai dengan penelitian yang dilakukan oleh Yoga \& Wenagama (2015) pembangunan pariwisata berkelanjutan harus dapat dilakukan dengan baik hal tersebut dikarenakan bahwa perkembangan pariwisata yang mampu menarik minat jumlah kunjungan wisatawan, menjaga minat beli wisatawan akan berdampak positif terhadap pertumbuhan ekonomi wilayah yang semakin maju kedepannya. (Pariwisata berkelanjutan (sustainable tourism) merupakan konsep pariwisata yang sangat penting untuk diperhatikan. Hal ini dikarenakan pariwisata berkelanjutan sangat memperhatikan dampak dari kegiatan pariwisata dalam segi ekonomi, sosial, dan lingkungan, baik saat ini maupun di masa yang akan datang. Ditinjau dari segi pariwisata sebagai usaha, maka usaha yang baik adalah yang dapat melindungi aset penting pariwisata tidak hanya untuk saat ini tetapi juga di masa mendatang (Yustita, 2020). Berdasarkan uraian latar belakang tersebut di atas penelitian ini

Pengaruh Kunjungan Wisatawan Dan Rata-Rata Pengeluaran Wisatawan Terhadap PAD Dan Pertumbuhan 
bertujuan untuk menganalisis pengaruh jumlah kunjungan wisatawan, rata-rata pengeluaran wisatawan, dan pendapatas asli daerah terhadap pertumbuhan ekonomi di Provinsi Bali.

\section{METODE PENELITIAN}

Penelitian ini dilakukan di Provinsi Bali Provinsi Bali dipilih dikarenakan potensi pariwisata sudah sangat menggeliat dan menjadi sektor utama bagi pendapatan masyarakat dan peluang pengembangan pariwisata yang ada di kabupaten/kota sedang digencarkan oleh pemerintah untuk pengembangan potensi kearifan lokal yang nantinya dapat terintegrasi menjadi pariwisata yang berkelanjutan dan berkesinambungan. Variabel eksogen dalam penelitian ini adalah jumlah kunjungan wisatawan $\left(\mathrm{X}_{1}\right)$ dan rata-rata pengeluaran wisatawan $\left(\mathrm{X}_{2}\right)$. Jumlah kunjungan wisatawan $\left(\mathrm{X}_{1}\right)$, merupakan seseorang ataupun sekelompok orang yang melakukan pariwisata yang bersifat sementara, yang bertujuan untuk mencari kebahagiaan. Dalam penelitian ini jumlah kunjungan wisatawan menggunakan data yang diperoleh dari Badan Pusat Statistik Provinsi Bali selama 30 tahun dari tahun 1990 sampai 2019 dalam satuan orang.

Penelitian ini menggunakan data panel yang terdiri atas data time series. Data time series yang digunakan berupa data tahunan selama 30 tahun dari tahun 1990 sampai tahun 2019, sehingga jumlah pengamatan yang dilakukan yaitu sebanyak 30 tahun yang terdiri dari data jumlah kunjungan wisatawan, rata-rata pengeluaran wisatawan, Pendapatan Asli Daerah, dan pertumbuhan ekonomi di tingkat Provinsi Bali. Teknik analisis data yang digunakan dalam penelitian ini adalah metode analisis jalur (Path Analysis). Analisis jalur merupakan perluasan dari analisis regresi linier berganda, untuk menaksir hubungan kausalitas antar variabel ditunjukkan oleh anak panah. Analisis ini digunakan untuk mengetahui hubungan langsung variabel independen terhadap variabel dependen dan hubungan tidak langsung yang melalui variabel mediasi (Suyana, 2016).

\section{HASIL DAN PEMBAHASAN}

Statistik deskriptif menyajikan informasi mengenai karakteristik variabel-variabel penelitian yaitu jumlah pengamatan, nilai minimum, nilai maksimum, nilai mean, dan standar deviasi. Untuk mengukur nilai sentral dari distribusi data dapat dilakukan dengan pengukuran rata-rata (mean) sedangkan standar deviasi merupakan perbedaan nilai data yang diteliti dengan nilai rata-ratanya.

Statistik deskriptif pada menunjukkan bahwa nilai minimum variabel jumlah kunjungan wisatawan $\left(\mathrm{X}_{1}\right)$ yang berwisata ke Bali yaitu sebanyak 490.729 orang dan jumlah kunjungan wisatawan maksimum berwisata di Bali yaitu sebanyak 6.275.210 orang. Rata-ratanya (mean) sebesar 2.227.003.37, yang lebih besar dari nilai standar deviasi sebesar 1.672.235.003, yang artinya berada dalam kondisi baik. Nilai minimum variabel rata-rata pengeluaran wisatawan $\left(\mathrm{X}_{2}\right)$ yaitu sebesar $\mathrm{Rp}$ 230.532,- dan rata-rata pengeluaran maksimum wisatawan yaitu sebesar $\mathrm{Rp} 2.631 .302,-$ ). Rata-ratanya (mean) sebesar 1.378.476.13 yang lebih besar dari nilai standar deviasi sebesar 823.717.620, yang artinya berada dalam kondisi baik.

Nilai minimum variabel pendapatan asli daerah $\left(\mathrm{Y}_{1}\right)$ yang diterima pemerintah Provinsi Bali yaitu sebesar Rp 39.112.938.000 dan pendapatan asli daerah maksimum yang diterima Pemerintah Provinsi Bali yaitu sebesar Rp 3.718.499.635.360). Rata-ratanya (mean) sebesar 1.164.164.473.099.97 yang lebih besar dari standar deviasi sebesar 1.263.507.416.847.154 yang

Pengaruh Kunjungan Wisatawan Dan Rata-Rata Pengeluaran Wisatawan Terhadap PAD Dan Pertumbuhan 
artinya berada dalam kondisi baik. Nilai minimum variabel pertumbuhan ekonomi $\left(\mathrm{Y}_{2}\right)$ yang pernah dialami oleh Provinsi Bali yaitu sebesar -4.04 persen dan pertumbuhan ekonomi maksimum yaitu sebesar 8.86 persen) Rata-ratanya (mean) sebesar 5.609.7 yang lebih besar dari nilai standar deviasi sebesar 2.617.39 yang artinya berada dalam kondisi baik.

Berdasarkan hasil penelitian dapat diketahui hubungan antar variabel penelitian yang merupakan koefisien jalur dalam penelitian ini. Koefisien jalur dapat dibuat dalam bentuk diagram jalur (Suyana, 2016).

Tabel 5.

Hasil Analisis Regresi Persamaan Struktur 1

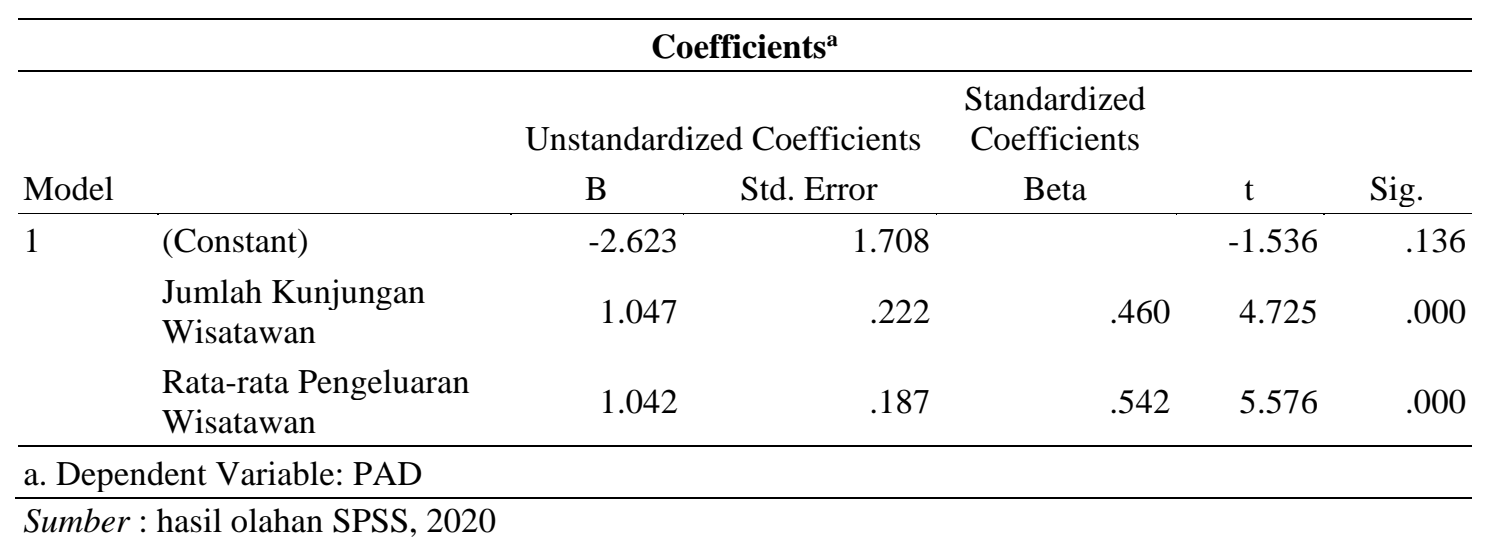

Tabel 6.

Hasil Analisis Regresi Persamaan Struktur 2

\begin{tabular}{llrrrrr}
\hline \multicolumn{6}{c}{ Coefficients $^{\mathbf{a}}$} \\
\hline \multirow{2}{*}{ Model } & & \multicolumn{7}{c}{ Standardized } & & \\
\hline 1 & & Unstandardized Coefficients & Coefficients & t & Sig. \\
\cline { 2 - 7 } & (Constant) & 1.490 & .260 & & 5.720 & .000 \\
& $\begin{array}{l}\text { Jumlah Kunjungan } \\
\text { Wisatawan }\end{array}$ & .095 & .035 & .074 & 2.710 & .012 \\
& $\begin{array}{l}\text { Rata-rata Pengeluaran } \\
\text { Wisatawan }\end{array}$ & .662 & .028 & .622 & 23.657 & .000 \\
& PAD & .072 & .002 & .457 & 29.327 & .000 \\
\hline
\end{tabular}

a. Dependent Variable: Pertumbuhan Ekonomi

Sumber : hasil olahan SPSS, 2020

$Y_{1}=0.460 X_{1}+0.542 X_{2}+0.270 e_{1}$

$Y_{2}=0.074 X_{1}+0.622 X_{2}+0.457 Y_{1}+0.063 e_{2}$

Uji kelayakan model atau yang sering disebut dengan uji F merupakan tahapan awal untuk mengidentifikasi model regresi yang diestimasi layak atau tidak. Tabel 7 menunjukkan nilai signifikan sebesar 0,000 yang lebih kecil dari nilai $\alpha=0,05$ maka model yang digunakan pada penilitian ini adalah layak. Hasil ini memberikan makna bahwa jumlah kunjungan wisatawan dan rata-rata Pengaruh Kunjungan Wisatawan Dan Rata-Rata Pengeluaran Wisatawan Terhadap PAD Dan Pertumbuhan 
pengeluaran wisatawan mampu memprediksi atau menjelaskan pendapatan asli daerah di Provinsi Bali.

Tabel 7.

Hasil Uji Kelayakan Model Struktur 1

\begin{tabular}{llrrrrr}
\hline \multicolumn{7}{c}{ ANOVA $^{\mathbf{b}}$} \\
\hline Model & & Sum of Squares & df & Mean Square & \multicolumn{1}{c}{ F } & \multicolumn{1}{c}{ Sig. } \\
\hline 1 & Regression & 66.977 & 2 & 33.489 & 171.350 & $.000^{\mathbf{a}}$ \\
& Residual & 5.277 & 27 & .195 & & \\
& Total & 72.254 & 29 & & & \\
\hline
\end{tabular}

a. Predictors: (Constant), Rata-rata Pengeluaran Wisatawan, Jumlah Kunjungan Wisatawan

b. Dependent Variable: PAD

Sumber : hasil olahan SPSS, 2020

Tabel 8 menunjukkan nilai signifikan sebesar 0,000 yang lebih kecil dari nilai $\alpha=0,05$ maka model yang digunakan pada penilitian ini adalah layak. Hasil ini memberikan makna bahwa jumlah kunjungan wisatawan, rata-rata pengeluaran wisatawan, dan pendapatan asli daerah mampu menjelaskan pertumbuhan ekonomi di Provinsi Bali.

Tabel 8.

Hasil Uji Kelayakan Model Struktur 2

\begin{tabular}{llcrrrr}
\hline \multicolumn{7}{c}{ ANOVA $^{\mathbf{b}}$} \\
\hline Model & & Sum of Squares & df & Mean Square & F & Sig. \\
\hline 1 & Regression & 21.686 & 3 & 7.229 & 1.9473 & $.000^{\text {a }}$ \\
& Residual & .097 & 26 & .004 & & \\
& Total & 21.783 & 29 & & & \\
\hline
\end{tabular}

a. Predictors: (Constant), PAD, Rata-rata Pengeluaran Wisatawan, Jumlah Kunjungan Wisatawan

b. Dependent Variable: Pertumbuhan Ekonomi

Sumber : Hasil olahan SPSS, 2020

Berdasarkan hasil analisis dapat diketahui bahwa jumlah kunjungan wisatawan berpengaruh positif dan signifikan terhadap pendapatan asli daerah di Provinsi Bali. Ini artinya bahwa ketika terjadi peningkatan jumlah kunjungan wisatawan ke bali, maka akan berdampak pula terhadap peningkatan jumlah PAD yang dihasilkan dan diterima oleh Provinsi Bali, begitu sebaliknya ketika jumlah kunjungan wisatawan mengalami penurunan, maka akan berdampak terhadap PAD yang juga akan mengalami penurunan.

Dapat disadari bahwa Provinsi Bali adalah salah satu pulau di Indonesia yang terkenal akan keunggulan pariwisatanya, karena pariwisata merupakan sub sektor utama yang diunggulkan di Bali yang mampu mendorong tumbuhnya perekonomian bali yang semakin maju dan berkesinambungan. Sehingga hal tersebutlah yang mendasari bahwa sektor pariwisata merupakan salah satu komponen penyumbang PAD yang cukup signifikan di Bali dari hasil pajak, retribusi dan pendapatan lainnya yang sah dari keberadaan pariwisata di Bali. Serta banyaknya wisatawan yang menghabiskan waktu berwisata ke Bali akan berpengaruh terhadap semakin besarnya devisa yang dihasilkan serta meningkatnya pendapatan masyarakat dari sektor ekonomi yang semakin produktif dalam menunjang pariwisata (Wijaya \& Kanca,2019).

Pengaruh Kunjungan Wisatawan Dan Rata-Rata Pengeluaran Wisatawan Terhadap PAD Dan Pertumbuhan 
Menurut penelitian Swastika \& Mahendra Yasa (2017) yang menyatakan bahwa jumlah kunjungan wisatawan berpengaruh positif dan signifikan terhadap pendapatan asli daerah, hal tersebut dikarenakan bahwa meningkatnya jumlah wisatawan yang berkunjung ke suatu wilayah akan membawa pengaruh besar terhadap bangkitnya perekonomian wilayah disekitar wisata, hal tersebut dikarenakan aktivitas wisata didaerah tersebut terkait dengan pengeluaran atau pola konsumsi ditempat wisata yang pada akhirnya akan mendukung kemajuan perekomian masyarakat sekitar, penyumbang pajak/retribusi objek wisata dan pada akhirnya akan membawa dampak kesejahteraan bagi masyarakat sekitar. Hal yang sesuai juga diungkapkan oleh Rantetadung (2012), yang menyatakan bahwa pengaruh kunjungan wisatawan sangat berarti untuk pengembangan industri pariwisata dan pendapatan asli daerah sehingga wisatawan domestik maupun wisatawan mancanegara tertarik untuk berkunjung dan menikmati aktivitas pariwisatanya.

Berdasarkan hasil analisis, dapat diketahui bahwa rata-rata pengeluaran wisatawan berpengaruh positif dan signifikan terhadap pendapatan asli daerah di Provinsi Bali. Hal ini berarti bahwa ketika rata-rata pengeluaran wisatawan yang berkunjung ke bali meningkat, maka akan berdampak bagi peningkatan pendapatan asli daerah. Begitu sebaliknya, ketika rata-rata pengeluaran wisatawan mengalami penurunan, maka pendapatan asli daerah yang dihasilkan akan semakin sedikit/rendah.

Menurut penelitian Munanda \& Syamsul, (2018), rata-rata pengeluaran wisatawan berpengaruh positif dan signifikan terhadap pendapatan asli daerah. Pengeluaran wisatawan merupakan indikator yang mempengaruhi nilai pendapatan yang diperoleh dari sektor pariwisata. Setiap biaya yang dikeluarkan berdampak positif, baik langsung maupun tidak langsung, khususnya bagi perekonomian daerah yang dikunjungi. Semakin tinggi pembelanjaan wisatawan di daerah yang dikunjungi oleh wisatawan, maka akan semakin besar manfaat yang diperoleh bagi penerimaan ekonomi daerah tersebut, karena setiap biaya/uang yang dikeluarakan oleh setiap wisatawan dapat diartikan sebagai pola konsumsi dari wisatawan tersebut selama mereka melakukan kegiatan pariwisata.

Hal senada juga diungkapkan oleh Anuar et al (2012), yang menyatakan bahwa setiap rupiah yang dibelanjakan wisatawan mancanegara pada suatu daerah tujuan wisata akan mendorong kegiatan ekonomi di daerah tujuan wisata yang dikunjungi yang pada akhirnya akan berdampak terhadap penerimaan/pendapatan wilayah. Dengan semakin besarnya pengeluaran wisatawan di daerh tujuan wisatawan akan dapat memberikan multiflier effect bagi keberadaan sektor perekonomian di sekitar tempat wisata, karena berkembanganya pariwisata tersebut menjadi harapan besar bagi kemajuan perekonomian masyarakat lokal yang semakin produktif, mampu memperoleh pendapatan secara mandiri untuk mendukung kesejahteraan hidupnya.

Berdasarkan hasil analisis diketahui bahwa jumlah kunjungan wisatawan berpengaruh positif dan signifikan terhadap pertumbuhan ekonomi di Provinsi Bali. Artinya bahwa ketika jumlah kunjungan wisatawan meningkat maka akan berdampak bagi peningkatan pertumbuhan ekonomi wilayah. Begitu sebaliknya ketika jumlah kunjungan wisatawan menurun, maka akan berdampak terhadap menurunnya pertumbuhan ekonomi di Provinsi Bali. Bali merupakan wilayah yang sangat potensial dari keberadaan pariwisatanya, ketika jumlah wisatawan meningkat yang berkunjung ke bali maka segala sektor perekonomian akan dapat tumbuh ke arah yang positif dan semakin produktif, sehingga dapat menggerakkan perekonomian menjadi semakin maju baik dari sisi keberlanjutan usaha, kesempatan kerja dan peningkatan pendapatan masyarakat yang pada akhirnya peningkatan pertumbuhan ekonomi wilayah.

Pengaruh Kunjungan Wisatawan Dan Rata-Rata Pengeluaran Wisatawan Terhadap PAD Dan Pertumbuhan 
Pembangunan Pariwisata khususnya dalam mendukung banyaknya jumlah wisatawan yang berkunjung ke Bali adalah sebagai penggerak dalam pembangunan perekonomian secara makro di Bali dan berperan penting di banyak negara termasuk di Indonesia, karena pariwisata adalah salah satu sektor produktif yang dapat memacu pertumbuhan perekonomian wilayah (Wijaya \& Kanca, 2019). Jumlah kunjungan wisatawan akan berpengaruh terhadap pertumbuhan ekonomi wilayah, hal tersebut dikarenakan bahwa banyaknya jumlah kunjungan wisatawan akan membawa pengaruh bagi aktivitas terkait dengan kegiatan berwisata seperti penyediaan akomodasi/penginapan, konsumsi, aktraksi/hiburan, transportasi, serta oleh-oleh atau buah tangan yang diperlukan oleh wisatawan, sehingga aktivitas yang dilakukan oleh wisatawan tersebut akan membawa pengaruh bagi bangkitnya perekonomian serta mendukung peningkatan pertumbuhan ekonomi wilayah menjadi semakin baik. Pernyataan tersebut di dukung oleh penelitian Amnar dkk.,(2017) yang menyatakan bahwa jumlah kunjungan wisatawan berpengaruh positif dan signifikan terhadap pertumbuhan ekonomi. Serta menurut penelitian (Patera \& Suardana, 2015), yang menyatakan bahwa dengan adanya aktivitas kunjungan wisatawan global akan dapat membangkitkan partisipasi masyarakat dalam mendukung pertumbuhan ekonomi wilayah. Peningkatan pertumbuhan ekonomi ini terjadi ketika jumlah wisatawan yang berkunjung meningkat, maka akan terjadi peningkatan terhadap aktivitas perekonomian wilayah dalam hal konsumsi barang dan jasa oleh wisatawan serta produksi barang dan jasa oleh pelaku pariwisata.

Berdasarkan hasil analisis dapat diketahui bahwa rata-rata pengeluaran wisatawan berpengaruh positif dan signifikan terhadap pertumbuhan ekonomi di Provinsi Bali. Artinya bahwa ketika rata-rata pengeluaran wisatawan mengalami peningkatan, maka akan berdampak positif terhadap meningkatnya pertumbuhan ekonomi wilayah. Begitu sebaliknya ketika rata-rata pengeluaran wisatawan menurun, maka pertumbuhan ekonomi akan mengalami penurunan.

Rata-rata pengeluaran wisatawan juga akan berdampak terhadap pertumbuhan ekonomi wilayah. Semakin banyak pengeluaran wisatawan di daerah tujuan wisata makan akan semakin banyak sektor pendukung pariwisata yang tergerak dalam penyediaan barang dan jasa yang pada akhirnya akan mendukung pergerakan pertumbuhan ekonomi wilayah yang semakin baik. Menurut penelitian Suartana dkk.,(2018), yang menyatakan bahwa rata-rata pengeluaran wisatawan berpengaruh positif dan signifikan terhadap pertumbuhan ekonomi wilayah, karena semakin banyak uang yang dikeluarkan oleh wisatawan akan mendukung terciptanya pergerakan ekonomi wilayah di daerah tujuan wisatawan yang semakin baik. Hal senada juga diungkapkan oleh penelitian Yoga \& Wenagama (2015), pengeluaran wisatawan berpengaruh signifikan terhadap pertumbuhan ekonomi wilayah. Semakin besar pengeluaran wisatawan untuk membeli dan menikmati segala bentuk barang dan jasa di daerah tujuan wisata, makan akan semakin tumbuhnya ekonomi pada wilayah yang bersangkutan.

Hasil analisis menunjukkan bahwa pendapatan asli daerah (PAD) berpengaruh positif dan signifikan terhadap pertumbuhan ekonomi di Provinsi Bali. Artinya bahwa ketika pendapatan asli daerah yang dihasilkan oleh pemerintah meningkat, maka akan berdampak positif terhadap peningkatan pertumbuhan ekonomi wilayah, hal sebaliknya, apabila pendapatan asli daerah mengalami penurunan, maka akan berdampak terhadap semakin melemahnya pertumbuhan ekonomi wilayah. Pendapatan asli daerah merupakan ukuran keaktivitasn dan semakin produktifnya sektor ekonomi/aset yang dimiliki daerah, ketika PAD ini meningkat, maka pergerakan ekonomi wilayah semakin baik dalam pemanfaatannya, sehingga hal tersebut yang mendukung pertumbuhan ekonomi wilayah yang semakin baik dan maju.

Pengaruh Kunjungan Wisatawan Dan Rata-Rata Pengeluaran Wisatawan Terhadap PAD Dan Pertumbuhan 
Pendapatan asli daerah merupakan pendapatan yang dimiliki oleh daerah dari hasil kekayaan yang dikelola/dimanfaatkan oleh daerah, baik dari sumber pendapatan, retribusi ataupun pendapatan yang sah menurut peraturan perundangan yang berlaku. Semakin tinggi pendapatan asli daerah pada wilayah yang bersangkutan, menandakan bahwa semakin banyaknya potensi lokal wilayah yang dapat termanfaatkan menjadi sumber peluang ekonomi wilayah yang pada akhirnya akan mendukung semakin baiknya pertumbuhan ekonomi wilayah dan kesejahteraan masyarakat. Menurut Penelitian Rory dkk.,(2016); Putri (2015); Kusumawati \& Wiksuana (2018), yang menyatakan bahwa pendapatan asli daerah berpengaruh positif dan signifikan terhadap pertumbuhan ekonomi wilayah, hal tersebut dikarenakan bahwa, semakin banyak besaran pendapatan asli daerah yang dihasilkan/diterima oleh wilayah menandakan bahwa pergerakan ekonomi diwilayah tersebut sangat potensial dan pada akhirnya akan mendukung pertumbuhan ekonomi wilayah yang semakin baik dan berkesinambungan.

Nilai z hitung sebesar $4.682>\mathrm{z}$ tabel sebesar 1,96, maka Ho ditolak dan Hi diterima. Artinya bahwa pendapatan asli daerah memediasi pengaruh jumlah kunjungan wisatawan terhadap pertumbuhan ekonomi di Provinsi Bali. Hal tersebut berarti bahwa ketika jumlah wisatawan dapat dimaksimalkan kedatangannya untuk berwisata ke Bali terus berpotensi mengalami peningkatan, maka hal tersebut akan berdampak baik bagi meningkatnya pendapatan asli daerah dan meningkatnya pertumbuhan ekonomi wilayah.

Nilai z hitung sebesar $5.516>\mathrm{z}$ tabel sebesar 1,96, maka Ho ditolak dan Hi diterima. Artinya bahwa pendapatan asli daerah memediasi pengaruh rata-rata pengeluaran wisatawan terhadap pertumbuhan ekonomi di Provinsi Bali. Hal ini menunjukkan bahwa ketika pendapatan asli daerah meningkat dengan pengoptimalan pemanfaatan sektor produktif ekonomi wilayah guna mendukung minat beli/ berbelanja wisatawan melalui peningkatan pengeluaran wisatawan maka akan berdampak baik bagi peningkatan pendapatan dan pertumbuhan ekonomi wilayah.

Tabel 9.

Pengaruh Langsung, Pengaruh Tidak Langsung dan Pengaruh Total Variabel

\begin{tabular}{lccc}
\hline & \multicolumn{2}{c}{ Pengaruh } & \multirow{2}{*}{ Total } \\
\cline { 2 - 3 } Hubungan Variabel & Langsung & Tidak Langsung Melalui & \\
\cline { 2 - 3 } & 0.460 & - & 0.460 \\
$\mathrm{X}_{1} \longrightarrow \mathrm{Y}_{1}$ & 0.542 & - & 0.542 \\
$\mathrm{X}_{2} \longrightarrow \mathrm{Y}_{1}$ & 0.074 & 0.210 & 0.284 \\
$\mathrm{X}_{1} \longrightarrow \mathrm{Y}_{2}$ & 0.622 & 0.248 & 0.870 \\
$\mathrm{X}_{2} \longrightarrow \mathrm{Y}_{2}$ & 0.457 & - & 0.457 \\
$\mathrm{Y}_{1} \longrightarrow \mathrm{Y}_{2}$ & & &
\end{tabular}

Sumber: data diolah dari SPSS, 2020

\section{SIMPULAN DAN SARAN}

Berdasarkan hasil pembahasan penelitian tersebut, maka kesimpulan yang dapat diberikan sebagai berikut. Jumlah kunjungan wisatawan dan rata-rata pengeluaran wisatawan berpengaruh positif dan signifikan terhadap pendapatan asli daerah di Provinsi Bali tahun 1990-2019. Jumlah kunjungan wisatawan, rata-rata pengeluaran wisatawan dan pendapatan asli daerah berpengaruh positif dan signifikan terhadap pertumbuhan ekonomi di Provinsi Bali tahun 1990-2019. Pendapatan asli daerah memediasi pengaruh jumlah kunjungan wisatawan dan rata-rata pengeluaran wisatawan terhadap pertumbuhan ekonomi di Provinsi Bali tahun 1990-2019.

Pengaruh Kunjungan Wisatawan Dan Rata-Rata Pengeluaran Wisatawan Terhadap PAD Dan Pertumbuhan 
Saran yang dapat diberikan sebagai berikut Bagi pemerintah, semoga hasil penelitian ini dapat menjadi bahan masukan, evaluasi dan perumusan kebijakan-kebijakan kedepannya untuk dapat membangun pariwisata Bali yang semakin berkelanjutan dan berkesinambungan dengan tetap mempertahankan kearifan lokal yang ada. Sehingga pariwisata yang ada di Bali benar-benar dapat memajukan perekonomian dan pemerataan pembangunan wilayah, memberikan peluang ekonomi dan kesejahteraan bagi masyarakat. Serta pariwisata yang telah berkembang saat ini supaya dapat lebih diperhatikan dan disempurnakan guna mendukung kesan para wisatawan yang berkunjung marasa puas dan bangga berwisata ke Provinsi Bali. Bagi para pelaku pariwisata yang ada di Indonesia pada umumnya dan di Bali pada khususnya, semoga hasil penelitian ini menjadi bentuk gambaran dalam upaya membangun pariwisata yang lebih baik dan maju kedepannya, mampu membangun kepercayaan bagi wisatawan baik domestik ataupun mancanegara, sehingga mereka mau berdatangan ke Bali lebih lama, mampu mendorong pengeluarannya, merasakan kepuasan dan kesan yang positif selama berlibur di Bali, sehingga hal tersebut yang dapat mendorong peningkatan pendapatan para pelaku usaha pariwisata yang nantinya akan berdampak bagi kesejahteraan masyarakat sekitar.

\section{REFERENSI}

Anuar, Ahmad Nazrin Aris., Ahmad, Habibah., Jusoh, Hamzah., and Hussain, Mohd Yusof. 2012. The Roles of Tourism System towards Development of Tourist FriendlyDestination Concept. Asian Social Science, 8(6), 146-155.

Anonym. 2020. Laju Pertumbuhan Ekonomi Kabupaten/Kota di Provinsi Bali Tahun 2015-2019, Badan Pusat Statistik Provinsi Bali, Denpasar.

-----. 2020. Pendapatan Asli Daerah Kabupaten/Kota di Provinsi Bali Tahun 2015-2019, Badan Pusat Statistik Provinsi Bali, Denpasar.

-----. 2020. Perkembangan Kunjungan Wisatawan Pada Kawasan Objek dan Daya Tarik Wisata Menurut Kabupaten/Kota di Bali Tahun 2015-2019 (Orang), Badan Pusat Statistik Provinsi Bali, Denpasar.

-----. 2020. Rata-rata Pengeluaran Wisatawan Mancanegara dan Domestik di Provinsi Bali, 2015-2019, Badan Pusat Statistik Provinsi Bali, Denpasar.

----. 2020. Buku Statistik Wisman Tahun 2018, Dinas Pariwisata Provinsi Bali, Denpasar.

Cole, S. 2006. Information and empowerment: The keys to achieving sustainable tourism. Journal of Sustainable Tourism. vol. 14(6), 629-644.

Darmawan, Agus Pande., dan I Wayan Wenagama. 2017. Pengaruh Pendapatan Asli Daerah, Pendidikan Dan Pengangguran Terhadap Kemiskinan Di Provinsi Bali. E-Jurnal EP Unud. 6(10). 1-9.

Dewi, Putu Kusuma ., dan Made Heny Urmila Dewi. 2019. Pengaruh Penanaman Modal Asing, Cadangan Devisa, dan APBN Terhadap Utang Luar Negeri Indonesia Melalui Impor Tahun 1996-2015. Jurnal Piramida.15(1), 121-151.

Ghimire, Krishna B. 2001. Regional tourism and South-South economic cooperation. The Geographical Journal. 99-110.

Helln, Angga Devy., dan R.B Soemanto, 2017. Pengembangan Obyek Dan Daya Tarik Wisata Alam Sebagai Daerah Tujuan Wisata Di Kabupaten Karanganyar. Jurnal Sosiologi DILEMA. 32(1).

Kusumawati, Lily., dan I Gusti Bagus Wiksuana. 2018. Pengaruh Pendapatan Daerah Terhadap Pertumbuhan Ekonomi Di Wilayah Sarbagita Provinsi Bali. E-Jurnal Manajemen Unud, 7(5), 1-34

Martina, Sopa. 2014. Dampak Pengelolaan Taman Wisata Alam Kawah Putih Terhadap Kehidupan Sosial Dan Ekonomi Masyarakat. Jurnal Pariwisata. 1(2). 45-64.

Munanda, Rizki., dan Syamsul Amar. 2018. Pengaruh Kunjungan Wisatawan Mancanegara, Rata-Rata Pengeluaran Dan Tingkat Hunian Hotel Terhadap Pendapatan Indonesia Pada Sektor Pariwisata. Jurnal Jurusan Ilmu Ekonomi Universitas Negeri Padang. 37-48.

Nurhasanah, Isye Susana., Nava Neilulfar Alvi., dan Citra Persada. 2017. Perwujudan Pariwisata Berkelanjutan Melalui Pemberdayaan Masyarakat Lokal di Pulau Pahawang, Pesawaran, Provinsi Lampung. Jurnal Tata Loka. 19(2). 10-20.

\footnotetext{
Pengaruh Kunjungan Wisatawan Dan Rata-Rata Pengeluaran Wisatawan Terhadap PAD Dan Pertumbuhan 
Patera, I Made., dan I Wayan Suardana. 2015. Model Hubungan Pariwisata, Kinerja Perekonomian dan Kemiskinan di Kabupaten Badung, Bali. Jurnal Piramida. 9(2), 95-105.

Pertiwi. (2014). Pengaruh kunjungan wisatawan, retribusi obyek wisata dan phr terhadap PAD kabupaten Gianyar. E-Jurnal EP Unud, 3(3), 45-68.

Purwanti, Novi Dewi., dan Retno Mustika Dewi. 2014. Pengaruh Jumlah Kunjungan Wisatawan terhadap Pendapatan Asli Daerah Kabupaten Mojokerto tahun 2006-2013. Jurnal ilmiah Program Studi Pendidikan Ekonomi. Fakultas Ekonomi: Universitas Negeri Surabaya.

Putri, Zuwesti Eka. 2015. Analisis Pengaruh Pendapatan Aslii Daerah (PAD), Dana Alokasi Umum (DAU) dan Inflasi terhadap Pertumbuhan Ekonomi Di Kabupaten/Kota Provinsi Jawa Tengah. Jurnal Bisnis dan Manajemen. UIN Syarif Hidayatullah Jakarta, 5 (2). 34-45.

Rimayanti, Ni Putu Sri., dan Sudarsana Arka. 2019. Analisis Faktor-Faktor Yang Mempengaruhi Pendapatan Petani Garam Di Kabupaten Karangasem. Jurnal Piramida. 15(2), 213-240.

Rory, Chindy Febry., Antonius Y Luntungan., dan Audie O Niode. 2016. Analisis Pengaruh Pendapatan Asli Daerah (Pad) Terhadap Pertumbuhan Ekonomi Di Provinsi Sulawesi Utara Tahun 2001-2013. Jurnal Berkala Ilmiah Efisiensi. 16(2), 60-78.

Spillane, J. James. 1994. Pariwisata Indonesia Siasat Ekonomi dan Rekayasa Kebudayaan. Yogyakarta: Kanisius.

Suartana, I Kadek Agus., Wayan Yogi Swara., dan I Ketut Sudiana. 2018. Pengaruh Kunjungan, Lama Tinggal, Pengeluaran Wisatawan, Hunian Hotel, dan Kurs Dollar Terhadap PDRB Provinsi Bali. E-Jurnal EP Unud, 7 (10), 2104-213.

Sukirno, Sadono. 2010. Makroekonomi Teori Pengantar. Jakarta: PT Raja Grafindo Persada.

Suyana Utama. 2016. Buku Ajar Aplikasi Analisis Kuantitatif. Denpasar: CV. Sastra Utama.

Wijaya, I Nengah., dan I Nyoman Kanca. 2019. Pembangunan Pariwisata Global Di Bali. Media Bina Ilmiah. 13(10), 67-90.

Yoga, I Gde Ary Dharma., dan I Wayan Wenagama. 2015. Pengaruh Jumlah Kunjungan Dan Pengeluaran Wisatawan Mancanegara Terhadap Produk Domestik Regional Bruto (Pdrb) Provinsi Bali Tahun 19962012. E-Jurnal EP Unud, 4 (2), 129 - 138.

Pengaruh Kunjungan Wisatawan Dan Rata-Rata Pengeluaran Wisatawan Terhadap PAD Dan Pertumbuhan 